\title{
A eurypterid from the lacustrine facies of the Early Devonian Campbellton Formation, New Brunswick, Canada
}

\author{
Randall F. MilleR ${ }^{1 *}$, Kirsten Kennedy ${ }^{2}$, And Martin R. Gibling ${ }^{2}$ \\ 1. Steinhammer Palaeontology Laboratory, Natural Science Department, New Brunswick Museum, Saint John, \\ New Brunswick E2K 1E5, Canada \\ 2. Department of Earth Sciences, Dalhousie University, Halifax, Nova Scotia B3H 4R2, Canada \\ ${ }^{*}$ Corresponding author < randall.miller@nbm-mnb.ca $>$
}

Date received 23 November 2011 gate accepted 23 December 2011

\begin{abstract}
The Early Devonian Campbellton Formation in northern New Brunswick, Canada, yielded its first eurypterid fossils in 1881. Based on recent taxonomic work, all known specimens have been assigned to Pterygotus anglicus, a large pterygotid first described from Scotland. These previously discovered eurypterids are from the western exposure of the Campbellton Formation and are believed to have inhabited a coastal deltaic setting, along with a rich vertebrate assemblage that included cephalaspids, placoderms, acanthodians, and sharks. The single eurypterid abdominal fragment described here as cf. Parahughmilleria was found in beds near the eastern exposure of the formation from a lacustrine facies. These beds are from classic plant-rich localities of the Campbellton Formation and, in addition to plants, have yielded the oldest land-animal assemblage in North America.
\end{abstract}

\begin{abstract}
RÉSUMÉ
Les premiers fossiles d'euryptéridés dans la Formation de Campbellton du Dévonien précoce, dansle nord du Nouveau-Brunswick, au Canada, ont été découverts en 1881. À la lumière de récents travaux de taxonomie, tous les spécimens connus ont été attribués à l'espèce Pterygotus anglicus, un ptérygotus de grande taille décrit initialement en Écosse. Ces euryptéridés découverts antérieurement proviennent d'un affleurement dans la partie ouest de la Formation de Campbellton et on croit que l'espèce a fréquenté un milieu du delta côtier, de pair avec un assemblage riche en vertébrés, qui a compris des céphalaspides, des placodermes, des acanthodiens et des requins. Le fragment abdominal unique d'euryptéridé décrit ici peut se comparer à celui de l'espèce Parahughmilleria et il a été découvert dans les couches d'un faciès lacustre, près de l'affleurement de la partie orientale de la formation. Ces couches proviennent généralement d’emplacements riches en végétaux de la Formation de Campbellton. En plus des plantes, ces sites ont permis de mettre à jour les assemblages d'animaux terrestres les plus anciens d'Amérique du Nord.
\end{abstract}

[Traduit par la redaction]

\section{INTRODUCTION}

Outcrops of the Early Devonian Campbellton Formation occur along the Bay of Chaleur-Restigouche River shoreline from Atholville east to Dalhousie, New Brunswick, Canada. The Campbellton Formation overlies the Val d'Amour Formation rhyolite dated at $407.4 \pm 0.8 \mathrm{Ma}$ (Wilson et al. 2004). Miospores in the Campbellton Formation place it in the Emphanisporites annulatus-Camarozonotriletes sextantii Assemblage Zone which corresponds approximately to the Polygnathus dehiscens to Polygnathus serotinus conodont zones of early Emsian to early late Emsian age (Richardson and McGregor 1986). The terminal date for the
Emsian is $397.5 \pm 2.7 \mathrm{Ma}$ (Ogg et al. 2008).

The western exposure of the Campbellton Formation was referred to as the "Atholville Beds" by Dineley and Williams (1968), and these beds are known for their wellpreserved vertebrate fauna (Young 1983; Miller et al. 2003; Turner and Miller 2008; Burrow et al. 2008), first described by Whiteaves (1881). Among the fossils Whiteaves described were eurypterids. New discoveries of both vertebrates and arthropods from the "Atholville Beds", beginning in the 1990s, resulted in a redescription of the eurypterid fauna (Miller 2007a, b) and assignment of all known specimens to Pterygotus anglicus Agassiz 1844, the large pterygotid first described from Scotland. Recent work to re-examine 
the paleoenvironment of the Campbellton Formation (Kennedy and Gibling 2011, and references therein) has resulted in the "Atholville Beds" being attributed to a coastal deltaic setting, with a marine influence, as demonstrated by rare occurrences of prasinophytes (tasmanitids) and acritarchs (Blieck and Cloutier 2000).

Farther east along the coast, outcrops near Maple Green, Point La Nim and Pin Sec Point comprise the classic plant-rich beds of the Campbellton Formation, including the second oldest evidence of wood (Gerrienne et al. 2011). These beds were described as representing a mix of wetland, alluvial-plain and lacustrine environments (Kennedy and Gibling 2011) and, in addition to plants, have yielded the oldest land animal assemblage in North America, including scorpion and arthropleurid fossils (Shear et al. 1996) and millipede fossils (Wilson 2006). A single abdominal eurypterid fragment was found in these beds in 1997, just east of Point La Nim, from a hard, grey siltstone unit approximately $1.6 \mathrm{~m}$ from beach level (Fig. 1). We describe the eurypterid fragment here as cf. Parahughmilleria.

Fractures in the bedding, overhanging trees, and the steep dip create an unstable cliff face and make fossil exploration difficult. Repeated searches have uncovered no additional material. The eurypterid bed occurs at a level $14 \mathrm{~m}$ above the base of section III in the marginal lacustrine facies association described by Kennedy and Gibling (2011). The outcrop consists of thick beds of horizontally stratified granule-pebble conglomerate, sharply overlain by massive to graded beds of grey siltstone. These in turn transition upwards to graded beds of red medium-coarse sandstone with lenses of granule conglomerate, and are overlain by pebble-cobble conglomerate. Resedimented volcanic material predominates within these strata, likely derived from nearby sources flanking the basin. The specimen is found within the grey siltstone unit, which is about $1 \mathrm{~m}$ thick and characterized by beds with centimetre-scale grading and organic-rich laminae, locally scoured below layers of coarse sandstone or granule conglomerate. Organic material is commonly found within this unit as well as in the overlying red sandstone, and includes fragments of Prototaxites and plant fragments up to $30 \mathrm{~cm}$ long. Although plant debris is common throughout the section, particularly plant-rich strata are found approximately $11 \mathrm{~m}$ below and $8 \mathrm{~m}$ above the cf. Parahughmilleria horizon. Collectively, plant taxa include Drepanophycus spinaeformis, Drepanophycus gaspianus, Zosterophyllum divaricatum, Sawdonia acanthotheca, Taeniocrada sp., and Spongiophyton minutissimum (Gensel et al. 1975; Gensel 1982; Gensel et al. 1991; P. Gensel personal communication 2010). The strata are interpreted as the result of underwater density flows that occurred during high-discharge flood events that carried plant material and volcanic sediment surrounding the lake into the marginal lake basin. Such flows would have rapidly buried any organisms inhabiting lacustrine waters.

\section{SYSTEMATIC PALEONTOLOGY}

\author{
Order Eurypterida Burmeister, 1843 \\ Family Adelophthalmidae Tollerton, 1989
}

Genus Parahughmilleria Kjellesvig-Waering, 1961

cf. Parahughmilleria sp.

(Figs. 2-4)

MATERIAL: Specimen NBMG 11012 consists of a part and counterpart of an articulated partial preabdomen of the opisthosoma (Fig. 2). The specimen is reposited in the Palaeontology Collection of the New Brunswick Museum (NBMG).

LOCALITY AND STRATIGRAPHY: Point La Nim $\left(48^{\circ} 03.97^{\prime} \mathrm{N}\right.$; $66^{\circ} 24.78^{\prime}$ W), west of Dalhousie, New Brunswick. Campbellton Formation, Emsian (Early Devonian).

DESCRIPTION: As very little of the animal is preserved, the specimen is assigned to cf. Parahughmilleria based on similarities in size and preabdomen shape to known members of the genus. All dorsal tergites of the preabdomen are represented, numbered 1 to 7 (Fig. 3). Features suggestive of Parahughmilleria include the lanceolate shape of the preabdomen, the presumed overall size of the animal, the presence of a large epimera on tergite 7 , and the ornamentation.

The total length of the preserved specimen is $57.7 \mathrm{~mm}$. The maximum width of the specimen is $22.7 \mathrm{~mm}$ at tergite 4. Maximum tergite lengths are (2) $7.5 \mathrm{~mm}$; (3) $6.7 \mathrm{~mm}$; (4) $7.3 \mathrm{~mm}$; (5) $8.8 \mathrm{~mm}$; (6) $9.4 \mathrm{~mm}$; (7) $9.8 \mathrm{~mm}$. Tergites are incomplete and widths cannot be determined. A shallow depression visible on tergites 3 to 5 suggests a mid-line. On tergites 2 and 3 the depression appears to split, possibly as a result of deformation of the specimen; however, this split-like appearance may represent a subtle expression of the underlying genital appendage. Published descriptions of Parahughmilleria indicate that the opisthosoma is widest at tergite 3 (Braddy 2000; Størmer 1973). Although tergite 3 is incomplete on this specimen, tergite 4 can be measured to the presumed mid-line $(14.5 \mathrm{~mm})$. Based on the reconstructed body dimensions of Parahughmilleria major Størmer, 1973, the measurements suggest that the Campbellton Formation specimen may have been about $125 \mathrm{~mm}$ long, about the maximum size of Parahughmilleria major.

A large epimera is seen on the posterior of mesosomal segment 7, a feature of Parahughmilleria noted by Braddy (2000) and found on both Parahughmilleria hefteri Størmer 1973 and Parahughmilleria major, which may represent different life stages of a single species (Poschmann and Tetlie 2006). Dorsal tergites are flattened over the ventral sternites. On the left the sternites are partially visible and extend beyond the tergites, offset with ventral tergites 2(?) to 5 .

The preabdomen is covered in lunules (Fig. 4), varying 


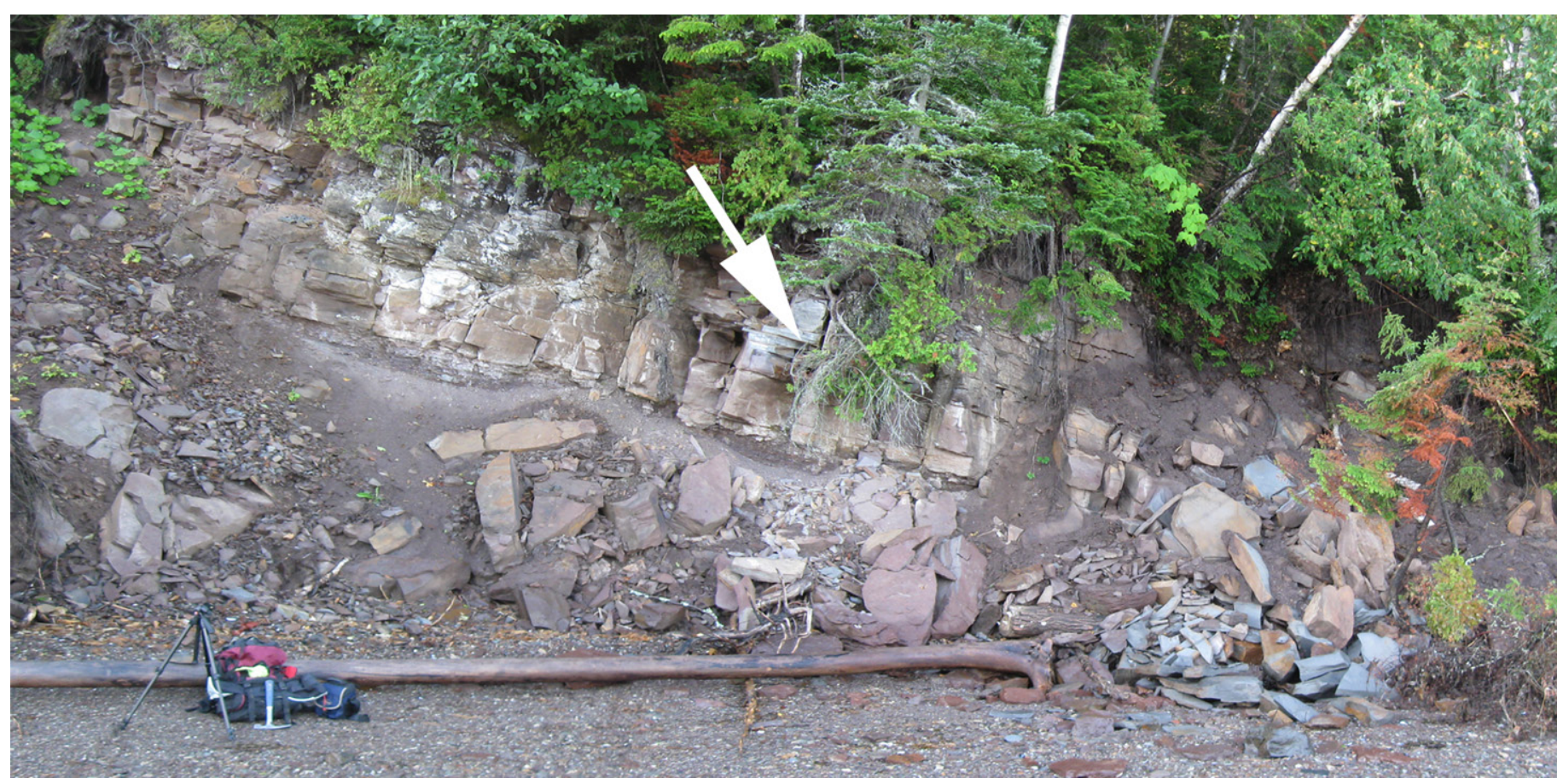

Fig. 1. Point La Nim site. Arrow indicates specimen location in the $14 \mathrm{~m}$ level of the marginal lacustrine facies association of Section III (Kennedy and Gibling 2011).
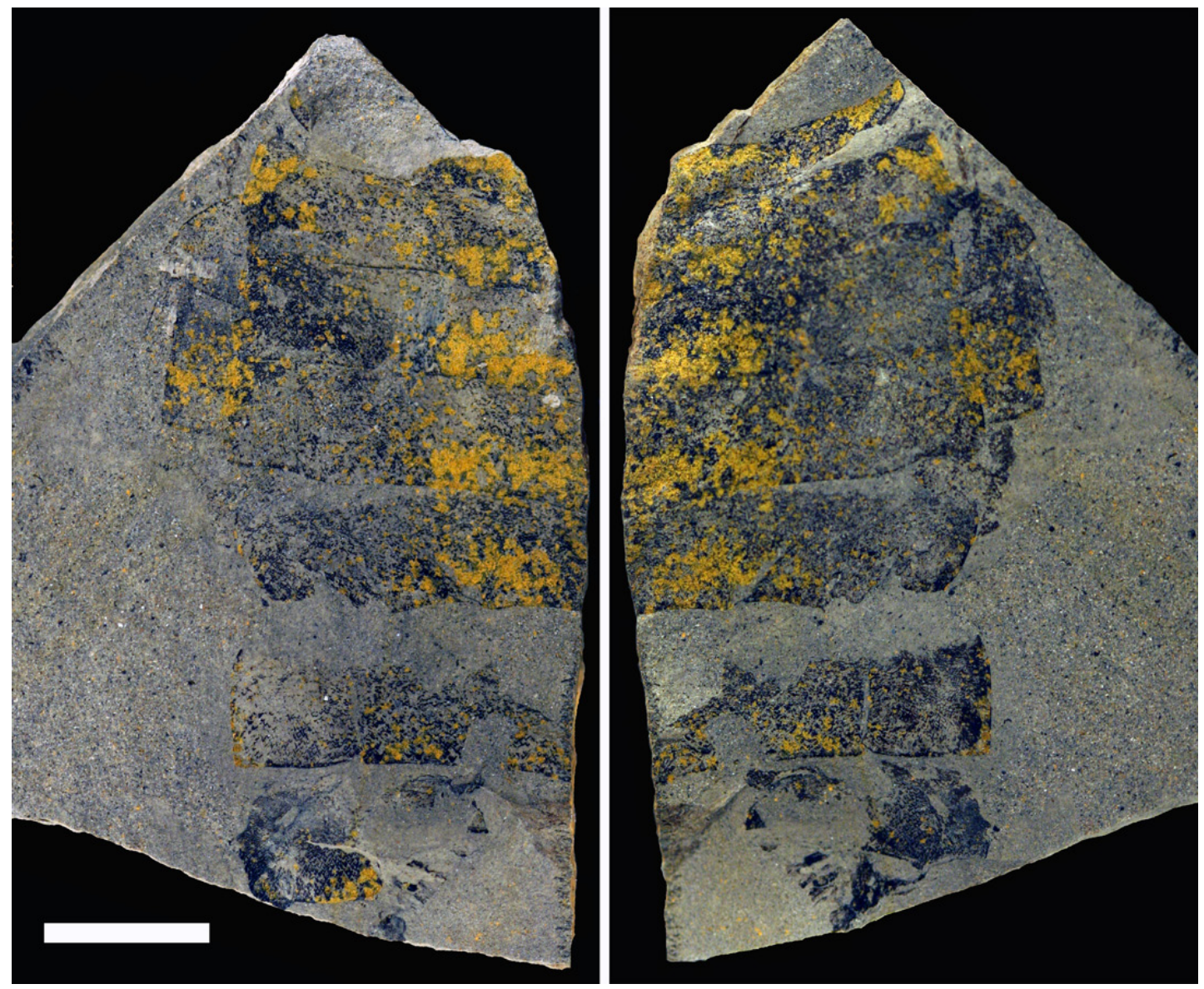

Fig. 2. Photograph of part and counterpart of cf. Parahughmilleria, NBMG 11012a (right), NBMG $11012 \mathrm{~b}$ (left). Scale bar equals $1 \mathrm{~cm}$. Specimen photographed in $70 \%$ ethanol. 


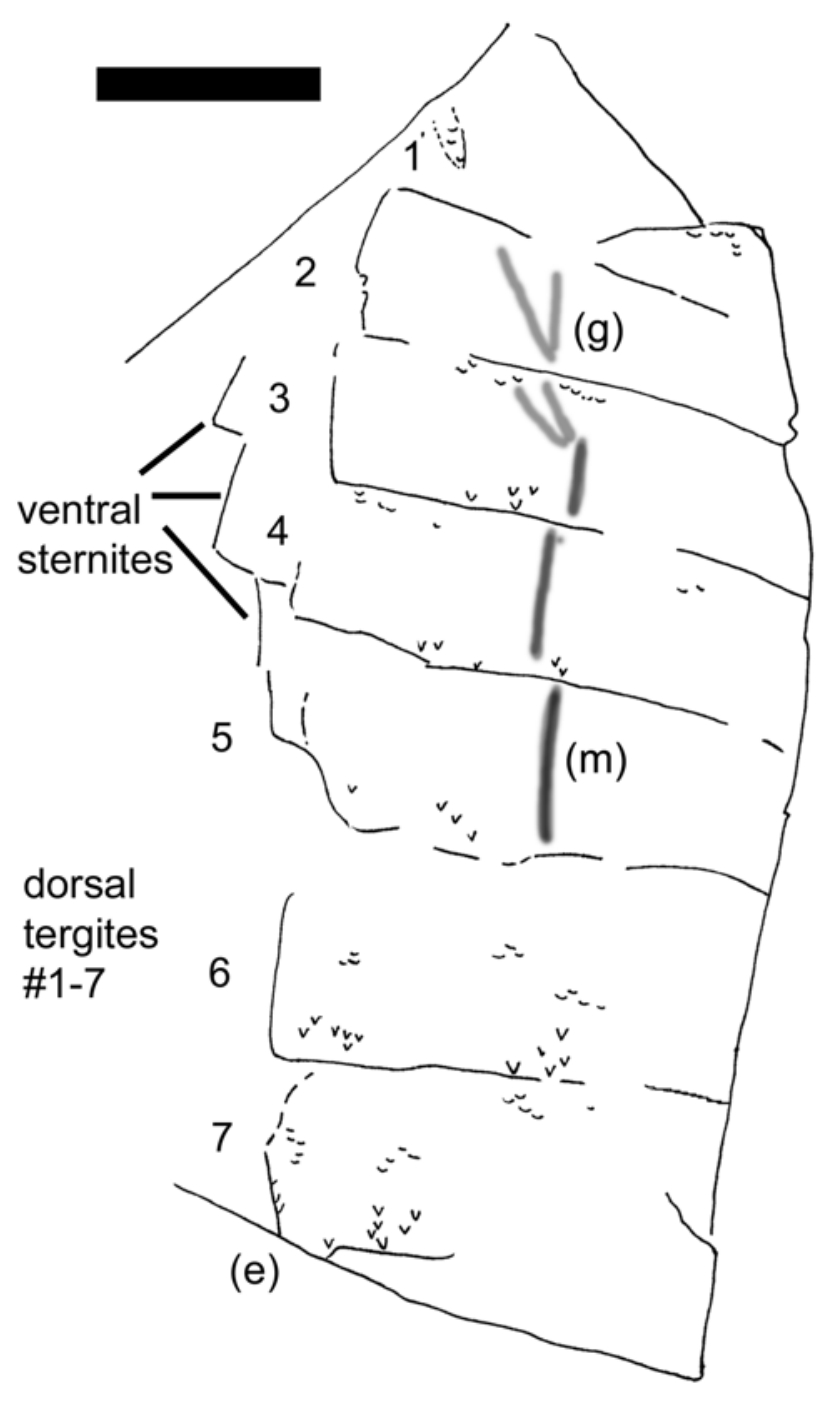

Fig. 3. Camera lucida drawing of cf. Parahughmilleria NBMG 11012b showing; tergites numbered 1 to 7 and sternites extending beyond margin of tergites; (e) lateral epimera on tergite 7 ; $(\mathrm{m})$ presumed mid-line; (g) 'expression' of genital appendage from ventral side. Scale bar equals $1 \mathrm{~cm}$.

from a semi-lunar sculpture on the proximal half of each tergite to a pointed (v-shaped) sculpture on the distal half of each tergite. Størmer (1973) described the crescentic to triangular ornamentation of importance in the taxonomy of the Hughmilleriidae, a family grouping that previously included Parahughmilleria and briefly described the ornament of Parahughmilleria hefteri and Parahughmilleria major.

REMARKS: The calculated body length of specimens of Pterygotus anglicus from the Campbellton Formation ranges from about $40 \mathrm{~cm}$ to about $170 \mathrm{~cm}$ (Miller 2007a, b). All of those specimens possess only a rounded semi-lunar sculpture, suggesting that the specimen described here as cf. Parahughmilleria is not likely a juvenile Pterygotus anglicus.

\section{DISCUSSION}

After 130 years of study focussed mainly on its fossil content, the remarkable window into an Early Devonian ecosystem thus revealed in the Campbellton Formation is now supported by a published record of the stratigraphy and synthesis of the paleoenvironment (Kennedy and Gibling 2011). The specimen described here as cf. Parahughmilleria provides an addition to the eurypterid fauna, previously represented only by Pterygotus.

Specimens of the genus Parahughmilleria have been described from numerous Early Devonian sites, in paleoenvironments ranging from shallow marine to freshwater (Tetlie and Poschmann 2008). In the Emsian of Alken an der Mosel, Germany (Størmer 1973), the paleoenvironment was described as marine to brackish (Poschmann and Tetlie 2006). In contrast, in the Emsian at Willwerath, also in the Rhenish Slate Mountains of Germany, Parahughmilleria lived in a shallow, brackish or freshwater terrestrial setting in a deltaic transitional facies, possibly a floodplain lake or interdistributary lagoon (Poschmann and Tetlie 2006). In the Midland Valley of Scotland, the paleoenvironment is described as both fluvial and lacustrine, associated with "Lake Forfar" (Braddy 2000). In Scotland, both pterygotids and hughmillerids are believed to have inhabited lacustrine environments, while stylonurid eurypterids inhabited fluvial environments. At the Devonian Trout Valley locality in Maine, USA, where a plant assemblage similar to the Campbellton Formation is known, Selover et al. (2005) described a juvenile eurypterid identified as cf. Parahughmilleria that was probably part of an estuarine assemblage.

Miller (2007a) discussed the Campbellton Formation pterygotid fauna as inhabiting estuarine or lagoonal paleoenvironments. Sizes of individuals suggested that juveniles and adults comprised the assemblage. Estuaries and lagoons may have been nurseries and the widely reported habitat of Pterygotus anglicus ranging from marine to freshwater, was perhaps dependent on stages of life history. The paleoenvironment for the specimen described herein, in a marginal lacustrine facies, is consistent with the setting described for Parahughmilleria from other Early Devonian sites. The two outcrop belts of the Campbellton Formation that have yielded eurypterids were interpreted as having been deposited in western and eastern sub-basins by Kennedy and Gibling (2011), possibly separated by a topographic barrier. In both sub-basins, sparse eurypterid material has been found at low stratigraphic levels in the formation, within a few tens of metres of the basal contact with the Val d'Amour 
Formation. However, the western sub-basin, which has marine indicators, has yielded pterygotid remains, whereas the eastern, lacustrine sub-basin has yielded cf. Parahughmilleria remains. Although too few specimens are available for a robust interpretation, it is possible that these occurrences provide an indication of paleoenvironmental tolerances, at least at this level in the Campbellton Formation.

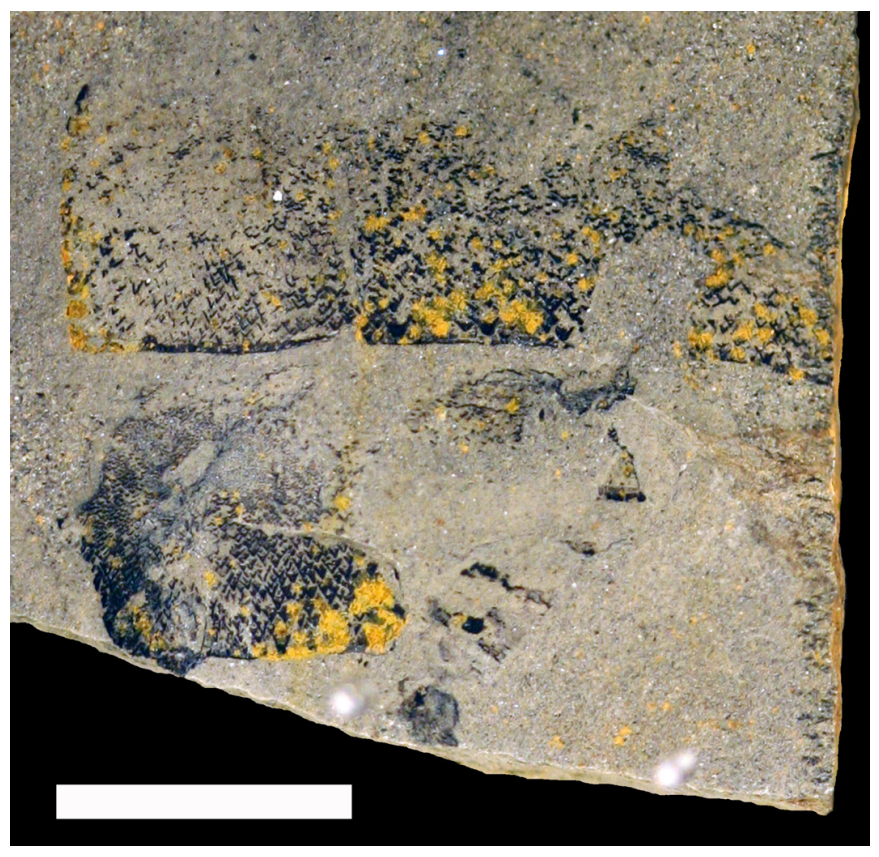

Fig. 4. Close-up of sculpture on tergites 6 and 7 of cf. Parahughmilleria NBMG 11012b. Scale bar equals $0.5 \mathrm{~cm}$. Specimen photographed in $70 \%$ ethanol.

\section{ACKNOWLEDGEMENTS}

We thank reviewers M. Cuggy and J. Dunlop, and editor R. Fensome for helpful comments to improve the manuscript. RFM thanks P. and W. Gensel for good company and discussions in the field over many seasons. KK and MRG are grateful for funding from a Discovery Grant to MRG from the Natural Sciences and Engineering Research Council of Canada (NSERC) and from an NSERC postgraduate scholarship to KK.

\section{REFERENCES}

Agassiz, L.R. 1844. Monographie des poissons fossiles du vieux grès rouge, ou système dévonien (Old Red Sandstone) des Iles britanniques et de Russie. Jent et Gassman.
Neuchatel, $171 \mathrm{p}$.

Blieck, A., and Cloutier, R. 2000. Biostratigraphical correlations of Early Devonian vertebrate assemblages of the Old Red Sandstone Continent. In Palaeozoic vertebrate biochronology and global marine/nonmarine correlation. Final report of IGCP 328 (1991-1996). Edited by A. Blieck and S. Turner. Courier Forschungsinstitut Senckenberg, 223, pp. 223-269.

Braddy, S.J. 2000. Eurypterids from the Early Devonian of the Midland Valley of Scotland. Scottish Journal of Geology, 36, pp. 115-122. http://dx.doi.org/10.1144/ sjg36020115

Burmeister, H. 1843. Die organization der Trilobiten, aus ihren lebenden Verwandten entwickelt; nebst systematischen Uebersicht aller zeither beschriben Arten. G. Reimer, Berlin, 148 p. http://dx.doi.org/10.5962/bhl. title.9086

Burrow, C.J., Turner, S., Desbiens, S., and Miller, R.F. 2008. Early Devonian putative gyracanthid acanthodians from eastern Canada. Canadian Journal of Earth Sciences 45, pp. 897-908.

Dineley, D.L., and Williams, B.P.J. 1968. The Devonian continental rocks of the Lower Restigouche River, Quebec. Canadian Journal of Earth Sciences, 5, pp. 945-953. http://dx.doi.org/10.1139/e68-091

Gensel, P.G. 1982. A new species of Zosterophyllum from the Early Devonian of New Brunswick. American Journal of Botany, 69, pp. 651-669. http://dx.doi. org $/ 10.2307 / 2442955$

Gensel, P.G., Andrews, H.N., and Forbes, W.H. 1975. A new species of Sawdonia with notes on the origin of microphylls and lateral sporangia. Botany Gazette, 136, pp. 50-62. http://dx.doi.org/10.1086/336782

Gensel, P.G., Chaloner, W.G., and Forbes, W.H. 1991. Spongiophyton from the late Lower Devonian of New Brunswick and Quebec, Canada. Palaeontology, 34, pp. 149168.

Gerrienne, P., Gensel, P.G., Strullu-Derrien, C., Lardeux, H., Steemans, P., and Prestianni, C. 2011. A simple type of wood in two Early Devonian plants. Science, 333, pp. 837. http://dx.doi.org/10.1126/science.1208882

Kennedy, K., and Gibling, M.R. 2011. The Campbellton Formation, New Brunswick, Canada: paleoenvironments in an Early Devonian terrestrial locality. Canadian Journal of Earth Sciences, 48, pp. 1561-1580. http://dx.doi. org/10.1139/e11-055

Kjellesvig-Waering, E.N. 1961. The Silurian Eurypterida of the Welsh Borderland. Journal of Paleontology, 35, pp. 789-835.

Miller, R.F. 2007a. Pterygotus anglicus Agassiz (Chelicerata: Eurypterida) from Atholville, Lower Devonian Campbellton Formation, New Brunswick, Canada. Palaeontology, 50, pp. 981-999. http://dx.doi.org/10.1111/j.14754983.2007.00683.x 
Miller, R.F. 2007b. Nineteenth century collections of Pterygotus anglicus Agassiz (Chelicerata; Eurypterida) from the Campbellton Formation, New Brunswick, Canada. Atlantic Geology, 43, pp. 197-209.

Miller, R.F., Cloutier, R., and Turner, S. 2003. The oldest chondrichthyan from the Early Devonian period. Nature, 425, pp. 501-504. http://dx.doi.org/10.1038/nature02001

Ogg, J.G., Ogg, G., and Gradstein, F.M. 2008. The Concise Geologic Time Scale. Cambridge University Press, Cambridge, $177 \mathrm{p}$.

Poschmann, M., and Tetlie, O.E. 2006. On the Emsian (Lower Devonian) arthropods of the Rhenish Slate Mountains: 5. Rare and poorly known eurypterids from Willwerath, Germany. Paläontologische Zeitschrift, 80, pp. 325-343.

Richardson, J. B., and McGregor, D. C. 1986. Silurian and Devonian spore zones of the Old Red Sandstone continent and adjacent regions. Bulletin of the Geological Survey of Canada, 364, $79 \mathrm{p}$.

Selover, R.W., Gastaldo, R.A., and Nelson, R.E. 2005. An estuarine assemblage from the Middle Devonian Trout Valley Formation of northern Maine. Palaios, 20, pp 192197. http://dx.doi.org/10.2110/palo.2004.p04-16

Shear, W.A, Gensel, P.G., and Jeram, A.J. 1996. Fossils of large terrestrial arthropods from the Lower Devonian of Canada. Nature, 384, pp. 555-557. http://dx.doi. org/10.1038/384555a0

Størmer, L. 1973. Arthropods from the Lower Devonian (Lower Emsian) of Alken an der Mosel, Germany, Pt. 3, Eurypterida, Hughmilleriidae. Senckenbergiana Lethaea, 54, pp. 119-179.

Tetlie, O.E. and Poschmann, M. 2008. Phylogeny and palaeoecology of the Adelophthalmoidea (Arthropoda; Chelicerata; Eurypterida). Journal of Systematic Pal- aeontology, 6, pp. 237-249. http://dx.doi.org/10.1017/ S1477201907002416

Tollerton, V.P. Jr. 1989. Morphology, taxonomy, and classification of the order Eurypterida Burmeister, 1843. Journal of Paleontology, 63, pp. 642-657.

Turner, S., and Miller, R.F. 2008. Protodus jexi Woodward, 1892 (Chondrichthyes), from the Lower Devonian Campbellton Formation, New Brunswick, Canada. Acta Geologica Polonica, 58, pp. 133-145.

Whiteaves, J. F. 1881. On some fossil fishes, Crustacea and Mollusca from the Devonian rocks at Campbellton, N.B., with description of five new species. Canadian Naturalist and Quarterly Journal of Science, 10, pp. 93-101.

Wilson, H.M. 2006. Juliformian millipedes from the Lower Devonian of Euramerica: implications for the timing of millipede cladogenesis in the Paleozoic. Journal of Paleontology, 80, pp. 638-649. http://dx.doi.org/10.1666/00223360(2006)80[638:JMFTLD]2.0.CO;2

Wilson, R. A., Burden, E. T., Bertrand, R., Asselin, E., and McCracken, A. D. 2004. Stratigraphy and tectono-sedimentary evolution of the Late Ordovician to Middle Devonian Gaspé Belt in northern New Brunswick: evidence from the Restigouche area. Canadian Journal of Earth Sciences, 41, pp. 527-551. http://dx.doi.org/10.1139/e04011

Young, V.T. 1983. Taxonomy of the arthrodire Phlyctaenius from the Lower or Middle Devonian of Campbellton, New Brunswick, Canada. Bulletin of the British Museum (Natural History) Geology Series, 37, pp. 1-35.

Editorial responsibility Robert A. Fensome 